\title{
Impact Ayo Ceting Towards Public Knowledge on Stunting at Public Healthcare Andalas Padang
}

\author{
Iip Permana ${ }^{1}$, Ulfia Izzati ${ }^{2}$, Yulia Hanoselina ${ }^{3}$, Rizki Syafril ${ }^{4}$ \\ \{ipaddr@fis.unp.ac.id ${ }^{1}$, ulfiaizzati@gmail.com², yuliahanoselina@fis.unp.ac.id³, \\ rizkisyafril@fis.unp.ac.id $\left.{ }^{4}\right\}$ \\ Universitas Negeri Padang, Padang ${ }^{1}$, Public Healthcare Andalas Padang, Padang ${ }^{2}$, Universitas Negeri \\ Padang, Padang ${ }^{3}$
}

\begin{abstract}
Andalas Healthcare, as one of the frontier public health services in Padang, has successfully implemented the national strategy for stunting prevention in the health sector through ICT education media based on an android application called Ayo Ceting. The android application intentions to empower the public as educator agents in the national campaign stunting prevention. However, there is no research about the impact of Ayo Ceting as education media on public knowledge of stunting. Therefore this research is conducted to find out the relation of those variables in Public Healthcare Andalas Padang. This research uses a quantitative quasi-experiment method and the subject are ten women of reproductive ages, ten pregnant mothers, and ten mothers with babies under five years old. The result shows significant differences in stunting knowledge before and after intervention through Ayo Ceting.
\end{abstract}

Keywords: Public Empowerment, ICT, Android Application, Stunting, Ayo Ceting.

\section{Introduction}

Stunting is a growth failure condition in malnourished children for a long time and identifies by being shorter than children of their age [1]. Stunting causes not only physical growth issues but also brain disorders. Furthermore, stunting affects ability, intellectual achievement, and productivity. Stunting not only impacts the individual but also national human capital development in long term goal. To prevent and reduce stunting, the Indonesian government produces several policies and programs. One of those is the National Strategy in Accelerated Prevention on Stunting 2018-2024. Prevention is carried out through campaigns using communication, information, and education materials to communities. One of the programs is improving nutrition attitudes and behavior through nutrition education [2].

Information and Communication Technology has become a viral media to all of the Indonesian society levels. It is reported by We are social in 2019, in which there were 355 million registered mobile phone devices from a total population of 268 million Indonesians and 150 million active internet users with 130 million internet access via mobile devices [3]. It means that more than half of Indonesia's population access the internet using mobile devices. Therefore mobile devices become a perfect tool to deliver information and communication.

Andalas Healthcare, as one of the frontier public health services in Padang, has successfully implemented the national strategy for stunting prevention in the health sector through ICT 
education media based on an android application called Ayo Ceting. Ayo Ceting can be downloaded and accessed by all the community levels in Indonesia through the Play Store. Ayo Ceting application is not only an educational media but also as a monitoring and evaluation media for pregnant women and infants, as well as a media for registration and direct online consultation to doctors [4]. The appearance of the Ayo Ceting application can be seen in the image below.
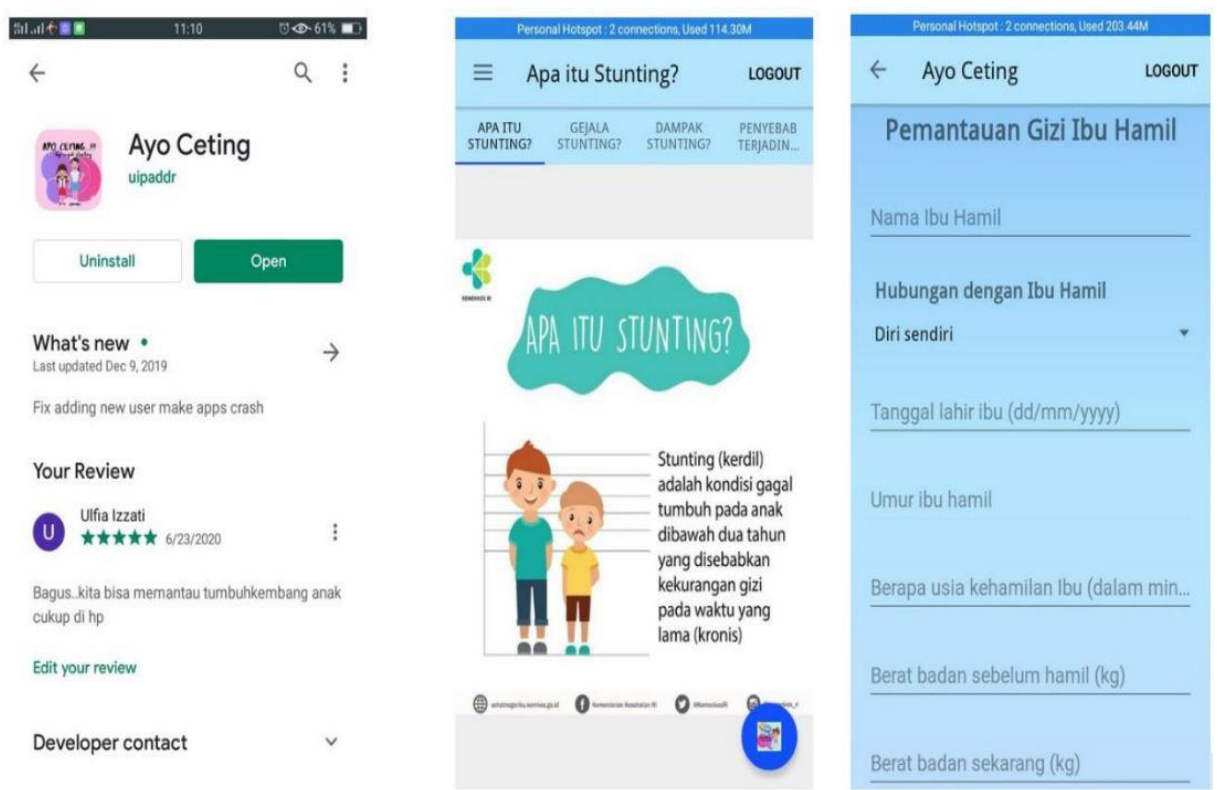

Fig. 1. Ayo ceting application [4].

Successful use of the Ayo Ceting application as a campaign media for preventing stunting through education requires stakeholder participation, especially communities. Therefore, it is urgent to determine the effect of using the Ayo Ceting application in increasing public literacy towards stunting.

\subsection{State of the art}

Stunting is a failure to flourish in children due to insufficient nutritional intake when the child is in the womb or when the child is in the first 1000 days of life [5]. The Minister of health fundamental research conducted in 2018 shows the decreasing prevalence of national stunting by $6.4 \%$ in a 5 -year. West Sumatra ranks 17 th place with a prevalence value of more than $40 \%$, the City of Padang is $11.86 \%$ [5]. The Indonesian Government has conducted some action to reduce the number of stunting in Indonesia. National strategy for acceleration and prevention of stunting provides knowledge and accelerate learning related to stunting to the public.

Studies related to stunting literacy introduces by several peoples [6], [7], [8], [9]. Saleh finds that $68.3 \%$ of the people in Mamminasa familiar with mobile phone media in his research related to ICT literacy. Fauziati uses flipchart media to deliver stunting literacy to brides-to-be, but this is not effective because the research subjects do not get in-depth knowledge about stunting prevention. Wahyurin, in his research, used brainstorming and audiovisual methods in delivering literacy to mothers with stunted children, but without monitoring and evaluating 
within a certain period to see the memory abilities of the research object. In another study, Nasrullah used ICT media based on augmented reality technology as a stunting literacy media and produce excellent results were obtained based on a questionnaire filled out by 30 respondents.

At the beginning of 2019, in the service area of Andalas Healthcare, stunting incidence is reached $26.9 \%$. Some programs rolled by the Andalas healthcare for educating civic are the house of nutrition and the pregnancy women classes. Thus both of those are still not optimal. Therefore, the Andalas healthcare innovated by developing an Android-based ICT media called Ayo Ceting as the stunting prevention education campaign.

\subsection{Literature Review \\ Stunting}

In Indonesia, being shorter is often considered a hereditary factor, even though nutrition is the main factor causing stunting. Indonesia government, through the National Team for the Acceleration of Poverty Reduction (TNP2K), has released the National Strategy (Stranas) for an acceleration of stunting prevention for 2019-2024 [5]. The objectives of the National Stunting Strategy are a) to ensure stunting prevention is a priority of the government and society at all levels; b) increase awareness and change the behavior of civics to prevent stunting; c) strengthening convergence through coordination and consolidation of central, regional and local programs and activities; d) increase access to nutritious food and promote food security; e) enhance monitoring and evaluation as a basis for ensuring quality service delivery, increasing accountability, and accelerating learning. Stranas goals to create five pillars. The Pillars as follows, commitment and leadership vision; National campaign and behavior change communication; convergence of central, regional, and local programs; food and nutrition security; monitoring and evaluation. One instrument from these pillars is the national campaign and behavior change communication throughout a campaign using communications, information, and education materials.

\section{Digital Literacy}

Humans can identify, understand, interpret, create, communicate, count, read, write, speak, and solve problems at several skill levels in everyday life. This extraordinary human ability is known as literacy. Thus, a person's level of understanding of the information they receive is a form of literacy.

ICT Media utilizes digital-based technology tools to manage communication and information. ICT media helps facilitate human life, start from archiving information and communication in ICT media to transmitting those to other parties. Internet is one of the ICT media widely used by all levels of society. Various information and communication passes on the internet can be used quickly, precisely, anytime, anywhere, and through any digital device that supports internet connectivity.

Digital literacy is knowledge and skills to use digital media to finding, evaluating, using, making, and utilizing information in a healthy, wisely, intelligently, carefully, precisely, and law-abiding manner to foster communication and interaction in everyday life [10]. Digital literacy aims to educate society in using information and communication wisely through digital technology. The fast growth of digital literacy provides opportunities for information disclosure to the public, so it needs to be accompanied by intelligence in analyzing data and content from the digital literacy presented [10]. 


\section{Ayo Ceting Program}

Andalas Healthcare is one of the frontiers of public health services in East Padang. It covers ten sub-districts (village) with an area of $8.15 \mathrm{Km} 2$. Since February 2019, it has been running Ayo Ceting (Ayo Cegah Stunting) program with the target group of pregnant women and mothers with babies/toddlers through knowledge transfer to create stunting understanding, awareness, and prevention behavior through 3 activity packages namely, 1) WhatsApp Group for pregnant mother; 2) nutrition house; and 3) Digital education: Ayo Ceting application based on Android [4]. Ayo Ceting application is an educational media for stunting prevention through display stunting campaign directly on the android device. It has the function of recording and monitoring the nutrition of pregnant women, babies, and toddlers. It also provides online registration and consultation services, so people do not need to bother registering and consulting doctors regarding health complaints they experience face to face.

\section{Methodology}

The research design used a quasi-experimental method with a control group to determine the cause and effect of Ayo Ceting application on several samples taken through the purposive sampling method [11].

The quasi-experimental method variables are divide into 2, namely the dependent/active variable (engineered / influencing variables) and the independent variable/attribute (variables are not engineer/influence). The dependent variable is ICT media, in this case, the Ayo Ceting application. The independent variable is the increase in community literacy.

In this study, Experimental units are ten women of childbearing age, ten pregnant women, and ten mothers of infants or toddlers in the working area of Andalas Healthcare, Padang City.

The research instrument is a question related to stunting being validity tested using the Pearson coefficient correlation and reliability testing using Cronbach's Alpha before pre-test and post-test intervention given later. The results analyzed using the normality test and the homogeneity test before the difference test given with the independent sample t-test. If a difference appears through a different test, the effectiveness analysis will run using N-Gain.

\section{Finding and Discussion}

The innovator of the Ayo Ceting application provides 30 questions regarding general stunting knowledge. Pearson correlation test uses to filter validity. Cronbach's alpha test uses to filter reliability. Both of the tests apply to 30 questions from the innovator. The result is 28 valid and reliable questions with a validity value of 0.951 , as shown in fig 2 . 


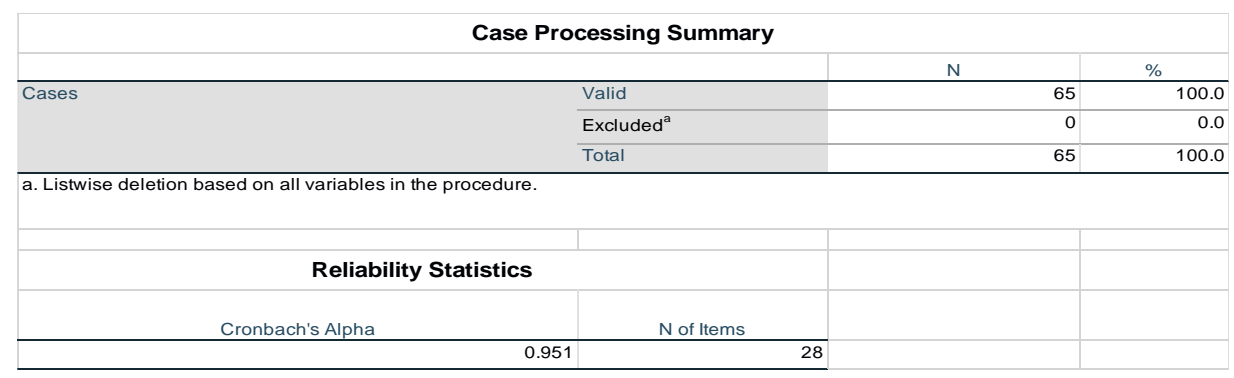

Fig. 2. Cronbach's Alpha reliability test result.

A normalization test applies to 15 subjects in the control group and 15 subjects in the experimental group resulted in both groups categorize as shown in fig 3 . Since 30 subjects participated in this research, which is lower than 50 samples, then the Shapiro-Wilk test is applied to both groups and results in both Sig. value is higher than 0,05 means both groups in the normal distribution.

\begin{tabular}{|c|c|c|c|c|c|c|c|}
\hline \multicolumn{8}{|c|}{ Tests of Normality } \\
\hline \multirow[b]{2}{*}{ Kelompok Kelas } & & \multicolumn{3}{|c|}{ Kolmogorov-Smirnov ${ }^{\mathrm{a}}$} & \multicolumn{3}{|c|}{ Shapiro-Wilk } \\
\hline & & Statistic & df & Sig. & Statistic & df & Sig. \\
\hline Nilai Post Test & Kelas Kontrol & 0.156 & 15 & $.200^{\circ}$ & 0.923 & 15 & 0.217 \\
\hline & Kelas Eksperimen & 0.196 & 15 & 0.126 & 0.910 & 15 & 0.138 \\
\hline
\end{tabular}

a. Lilliefors Significance Correction

Fig. 3. Shapiro-Wilk normality test result.

Afterward, the homogeneity test also applies to data to validate that we will be allowed to perform an independent T-test next. Both the control group and the experiment group results higher than 0,05 . Therefore, data fulfill the homogeneity requirement as shown in fig 4 and allows for comparison.

\begin{tabular}{|c|c|c|c|c|c|}
\hline \multicolumn{6}{|c|}{ Test of Homogeneity of Variance } \\
\hline & & Levene Statistic & df1 & $\mathrm{df2}$ & Sig. \\
\hline \multirow{4}{*}{ Nilai Post Test } & Based on Mean & 0.814 & 1 & 28 & 0.375 \\
\hline & Based on Median & 0.696 & 1 & 28 & 0.411 \\
\hline & $\begin{array}{l}\text { Based on Median and with } \\
\text { adjusted df }\end{array}$ & 0.696 & 1 & 26.758 & 0.411 \\
\hline & Based on trimmed mean & 0.803 & 1 & 28 & 0.378 \\
\hline
\end{tabular}

Fig. 4. Homogeneity test result.

As shown in fig 5, this research finds that the control group's mean value is 72.80 . The experiment group's mean value is 84,53 . The experiment groups mean higher than control groups, but we need to know if this difference between the two groups is significant by using an independent t-test. 


\begin{tabular}{|c|c|c|c|c|c|c|}
\hline \multicolumn{7}{|c|}{ Group Statistics } \\
\hline Kelompok Kelas & & $\mathrm{N}$ & & Mean & Std. Deviation & Std. Error Mean \\
\hline \multirow[t]{2}{*}{ Nilai Post Test } & Kelas Kontrol & & 15 & 72.80 & 9.704 & 2.506 \\
\hline & Kelas Eksperimen & & 15 & 84.53 & 8.262 & 2.133 \\
\hline
\end{tabular}

Fig. 5. Group statistics from t-test result.

As shown in fig 6, from the previous, we find that data fulfill homogeneity condition, so that at this step, equal variance assumed will take into account for check of significance. Furthermore, we saw on the Sig (2-tailed) where the value is 0.001 , and this value is lower than 0.025 , so we find that the means from both groups are significant.

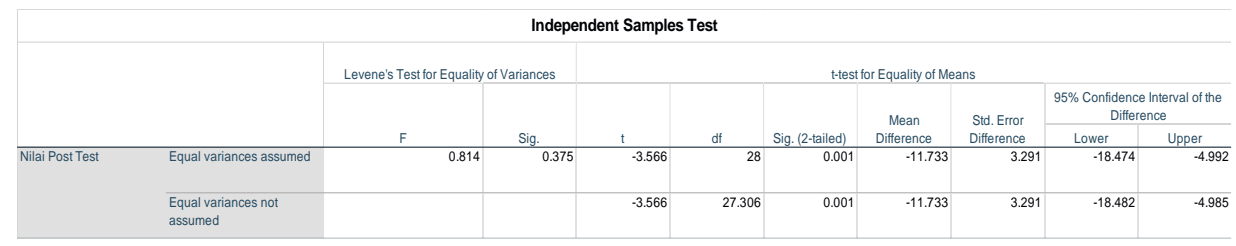

Fig. 6. Independent Samples t-test result.

Finally, the N-gain test takes into account, and we find results as following. The control group effectivity is $51.2160 \%$, but the experiment group effectivity is $80.0435 \%$. Therefore, the control group falls into moderate, while the experiment group falls into high classification. To summarize, Ayo Ceting intervention as literacy media for stunting is very significant and very effective increasing public knowledge on stunting.

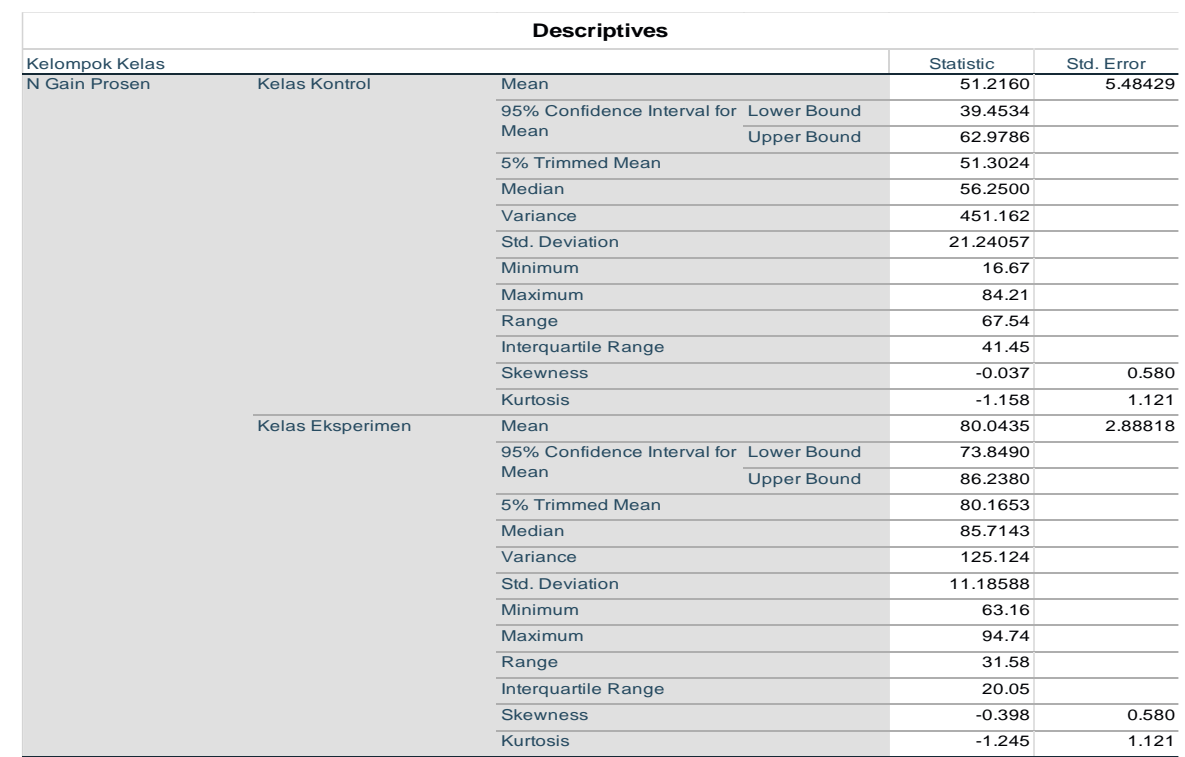

Fig. 7. N-gain test result. 


\section{Conclusion}

The mean of the control groups while compare to the experiment groups is significant using an independent T-test. N-Gain test result classified control group in moderate classification and experiment group in high classification. It means the intervention of Ayo Ceting application as stunting literacy media is very significant and very effective. It is consistent with previous research, which states that the intervention with augmented reality-based ICT media gives perfect results based on questionnaires given to respondents [7].

In addition to significant intervention of stunting knowledge in the working area of the Andalas Healthcare, the Ayo Ceting application also provides easy access to information anytime and anywhere according to their respective preferences. As reported by We are social, the Increasing use of smartphone devices also adding public opportunity to access information related to stunting through the Ayo Ceting application because this application utilizes an Android-based smartphone as an ICT media. Therefore Ayo Ceting becomes a promising instrument in a campaign using communication, information, and education material.

\section{References}

[1] S. H. Waliulu and D. Ibrahim, "Pengaruh Edukasi Terhadap Tingkat Pengetahuan dan Upaya Pencegahan Stunting Anak Usia Balita,” Penelit. Kesehat. Suara Forikes, vol. 9, no. 4, pp. 269-272, 2018.

[2] M. Dewi and M. Aminah, "Pengaruh Edukasi Gizi terhadap Feeding Practice Ibu Balita Stunting Usia 6-24 Bulan (The Effect of Nutritional Knowledge on Feeding Practice of Mothers Having Stunting Toddler Aged 6-24 Months)," Indones. J. Hum. Nutr., vol. 3, no. 1, pp. 1-8, 2016, doi: 10.21776/ub.ijhn.2016.003.suplemen.1.

[3] Report: We Are Social and Hootsuite, "Digital DATA OVERVEW 2019: Indonesia," Glob. Digit. Insights, p. 17, 2019.

[4] I. Permana, "Inovasi Pelayanan Kesehatan Publik Berbasis E-Government ( Studi Kasus: Inovasi Ayo Ceting Di Puskesmas Andalas)," vol. 4, no. 1, pp. 25-37, 2020, doi: 10.24036/jess/vol4-iss1.

[5] TNP2K, "Strategi Nasional Percepatan Pencegahan Anak Kerdil (Stunting)," Jakarta, 2018.

[6] B. Saleh, "Information and Communication Technology (ICT) Literacy of Community in Mamminasata Region,” J. Pekommas, vol. 18, no. 3, pp. 151-160, 2015.

[7] M. Nasrullah and M. N. Malik, "Pengembangan Teknologi Augmented Reality Sebagai Media Edukasi Masyarakat Terhadap Gizi Buruk," no. 2007, 2017.

[8] I. S. Wahyurin, A. N. Aqmarina, H. A. Rahmah, A. U. Hasanah, and C. N. B. Silaen, "Pengaruh edukasi stunting menggunakan metode brainstorming dan audiovisual terhadap pengetahuan ibu dengan anak stunting," Ilmu Gizi Indones., vol. 2, no. 2, p. 141, 2019, doi: 10.35842/ilgi.v2i2.111.

[9] N. Fauziatin, A. Kartini, and S. . Nugraheni, "Pengaruh Pendidikan Kesehatan dengan Media Lembar Balik Tentang Pencegahan Stunting Pada Calon Pengantin," VISIKES J. Kesehat. Masy., no. agustus, pp. 224-233, 2019.

[10] Kemdikbud, "Materi Pendukung Literasi Digital," 2017.

[11] D. Thomas, T. Donald, D. Hastjarjo, and C. Quasi-, "QUASI-EXPERIMENTATION: DESIGN \& ANALYSIS ISSUES FOR FIELD SETTINGS,” Analysis, no. 1979, pp. 1-15, 2008. 